\title{
UPAYA PENINGKATAN HASIL BELAJAR SISWA PADA MATERI INTEGRASI NASIONAL DALAM BINGKAI BHINNEKA TUNGGAL IKA MENGGUNAKAN MODEL PEMBELAJARAN DISCOVERY LEARNING PADA SISWA KELAS X MIPA SMA NEGERI 1 SAMIGALUH
}

\author{
Nurjanah \\ SMA Negeri 1 Samigaluh \\ ppknnurjanah@gmail.com
}

\begin{abstract}
Abstrak: Penelitian ini bertujuan untuk mengetahui upaya meningkatkan hasil belajar PKn pada materi Integrasi Nasional dalam Bingkai Bhinneka Tunggal Ika di kelas X MIPA SMA Negeri 1 Samigaluh Kulonprogo melalui penerapan model pembelajaran discovery learning. Jenis penelitian ini adalah penelitian tindakan kelas yang terdiri dari empat tahapan yaitu perencanaan, pelaksanaan, observasi, dan refleksi. Subjek penelitian adalah siswa kelas X MIPA SMA Negeri 1 Samigaluh Kulonprogo. Teknik pengumpulan data menggunakan wawancara, observasi, dan dokumentasi. Teknik analisis data yang digunakan dalam penelitian ini adalah deskriptif kuantitatif. Berdasarkan hasil penelitian disimpulkan bahwa metode discovery learning dapat meningkatkan hasil belajar PKn siswa kelas X MIPA SMA Negeri 1 Samigaluh. Hasil penelitian menunjukkan bahwa nilai rata-rata pra siklus 71,6 dengan presentase ketuntasan sebesar 22,2\%. Nilai rata-rata tes siklus I yaitu 76,3 dengan presentase ketuntasan sebesar 50\% dan nilai rata-rata tes siklus II yaitu 85,6 dengan presentase ketuntasan sebesar $100 \%$.
\end{abstract}

Kata kunci: discovery learning, hasil belajar PKn

\section{EFFORTS TO IMPROVE STUDENT LEARNING OUTCOMES IN NATIONAL INTEGRATION MATERIALS IN THE BHINNEKA TUNGGAL IKA BY USING DISCOVERY LEARNING MODEL IN MIPA CLASS OF SMA NEGERI 1 SAMIGALUH}

\begin{abstract}
The research aims to find out the improvement of student learning outcomes of Civics Lesson on the national integration material in the Bhinneka Tunggal Ika frame by using discovery learning model on MIPA Class of SMA Negeri 1 Samigaluh. The research is Class Action Research which consists of 4 stages, Planning, Implementing, Observation, and Reflection. The subject research was grade X students MIPA of SMA Negeri 1 Samigaluh. The data collecting technique was using interview, observation, and documentation. The research was conducted collaboratively between the teachers and researcher, so that the researcher was actively involved from the very beginning until the ending of the research. The indicator was found from the learning outcome improvements of Civics Lesson. The data analysis technique used in the research was qualitative description. Based on the research result, it is concluded that discovery method leads to the learning outcome improvements of Civics Lesson for grade X students MIPA of SMA Negeri 1 Samigaluh. The research shows that the pre-cycle average is 71,6 by completeness percentage of 22,2\%. The cycle 1 score average is 76,3 by completeness percentage of 50\%, and the cycle 2 score average is 85,6 by completeness percentage of $100 \%$.
\end{abstract}

Keywords: discovery learning, the outcomes of civics lesson

\section{PENDAHULUAN}

Sesuai dengan ketentuan pasal 37 UU No. 20 tahun 2003 menyatakan bahwa pendidikan kewarganegaraan dimaksudkan untuk membentuk peserta didik menjadi warga negara yang baik, untuk menjadikan bangsa yang berkarakter Pancasilais, sehingga PKn (Pendidikan Kewarganegaraan) merupakan salah satu mata pelajaran yang wajib diajarkan di sekolah menengah atas. Dalam menjalankan misi sosio akademisnya, PKn berperan menumbuh kembangkan kopetensi siswa dalam aspek kecakapan akademisnya terutama dalam pengembangan kemampuan berpikir kritis, analisis, reflektif, menemukan sendiri dan memecahkan masalah serta bertanggung jawab yang berkaitan dengan pengembangan kesadaran hidup bermasyarakat, berbangsa dan bernegara. Dalam menjalankan misi sosio kulturalnya PKn berkewajiban memberikan fasilitas kepada siswa untuk mempraktekan pengetahuan, nilai-nilai, dan keterampilan yang telah dimilikinya untuk dapat disumbangkan pada berbagai bentuk partisipasi sosial kemasyarakatan sesuai dengan tingkat perkembangan dan kemampuan siswa. Siswa dalam hal ini dapat berpartisipasi aktif dalam beberapa bentuk pengabdian kepada masyarakat.

Pendidikan kewarganegaraan merupakan salah satu mata pelajaran yang dapat membentuk diri yang beragam dari segi agama, sosio, cultural, 
bahasa, usia, untuk menjadi warga negara yang cerdas, terampil dan karakter yang dilandasi oleh UUD 1945. Hal ini sesuai dengan yang dikemukakan oleh Depdiknas (2005:34), bahwa Pendidikan kewarganegaraan merupakan mata pelajaran yang secara umum bertujuan untuk mengembangkan potensi individu warga negara Indonesia, sehingga memiliki wawasan, sikap, dan keterampilan kewarganegaraan yang memadai dan memungkinkan untuk berpartisipasi secara cerdas dan bertanggung jawab dalam berbagai kehidupan bermasyarakat, berbangsa dan bernegara. Jelas bagi kita bahwa PKn bertujuan mengembangkan potensi individu warganegara, Untuk mencapai visi, misi dan tujuan PKn tersebut, seorang guru hendaknya mampu merancang pembelajaran di kelas secara kreatif, dan inovatif. Namun dalam realitanya selama ini pembelajaran PKn hanya menggunakan metode ceramahdan cenderung berorientasi pada konsep-konsep yang sifatnya sangat teoritis, di samping itu guru cenderung monoton tanpa memperhatikan media dan model pembelajaran yang tepat digunakan untuk dapat meningkatkan keaktifan dan hasil belajar PKn sehingga siswa menganggap bahwa pembelajaran PKn sangat membosankan.

Berdasarkan observasi awal di lapangan bahwa terjadi permasalahan terkait dengan hasil belajar siswa khususnya siswa kelas X MIPA SMA Negeri 1 Samigaluh Kulonprogo yakni KKM (Kriteria ketuntasan Minimal) untuk pelajaran PKn di kelas X adalah 76 akan tetapi nilai-nilai rata-rata siswa yang diperoleh adalah 71,6 dengan ketuntasan 22,2\%. Mencermati tentang rendahnya nilai yang dicapai oleh siswa berada di bawah standar ketuntasan minimal yang ditentukan yaitu dari kriteria Ketuntasan Minimal (KKM) menunjukan sebagian siswa masih di bawah standar. Berkenaan dengan keadaan tersebut menuntut guru untuk memulihkan situasi pembelajaran dengan harapan mampu memenuhi KKM yang ditentukan. Masalah di atas dapat menjadi salah satu penyebab mengapa pembelajaran PKn di sekolah belum memenuhi harapan di dalam hasil yang diperolehnya. Menyikapi permasalahan di atas diperlukan metode atau model pembelajaran yang tepat untuk meningkatkan hasil belajar siswa dalam pembelajaran PKn.

Hasil belajar siswa pada hakekatnya adalah perubahan tingkah laku sebagai hasil belajar dalam pengertian yang lebih luas mencakup bidang kognitif, afektif, dan psikomotorik. Dimyati dan Mudjiono (2006: 25) juga menyebutkan hasil belajar merupakan hasil suatu dari interaksi tindak belajar dan tindak mengajar. Dari sisi guru, tindak mengajar diakhiri dengan proses evaluasi hasil belajar. Dari sisi siswa, hasil belajar merupakan berakhirnya pengajaran dari puncak proses belajar.

Benjamin S, Bloom (Dimyati dan Mudjiono, 2006: 26-27) menyebutkan enam jenis perilaku ranah kognitif, yaitu pengetahuan, pemahaman, penerapan, analisis, sintesis dan evaluasi.

Sugihartono, dkk (2007: 149), menyebutkan faktor-faktor yang mempengaruhi hasil belajar adalah faktor internal dan faktor eksternal. Faktor internal adalah faktor yang ada dalam dari individu yang sedang belajar, terdiri atas faktor jasmaniah dan faktor psikologis. Faktor eksternal adalah faktor yang ada di luar individu. Faktor eksternal meliputi: faktor keluarga, faktor sekolah, dan faktor masyarakat.

Berdasarkan hasil pengamatan yang dilakukan mengenai hasil belajar PKn yang diperoleh siswa kelas X SMA Negeri1 Samigaluh Kulonprogo, maka peneliti tertarik untuk mencoba menggunakan model pembelajaran discovery learning.

Zulfiani (2009: 117) menyebutkan bahwa model adalah suatu pola yang bisa digunakan untuk mendesain suatu pengajaran yang meliputi sumber, subjek, lingkungan dan kurikulum. Belajar adalah proses seorang pendidik menggabungkan pengetahuan baru dengan pengetahuan lama.

Model pembelajaran discovery learning berakar dari faham konstruktivis (konstruktivisme). Teori ini menyebutkan bahwa siswa harus mencari sendiri dan mentransformasikan informasi, mengecek informasi baru dan melakukan revisi apabila aturan-aturan itu tidak lagi sesuai (Trianto, 2007: 13).

Abruscato dan A DeRosa (2010: 45) mengatakan:

"Learning is an ongoing process, in which the learner integrates new knowledge with previous knowledge and discovers new ways of thinking, acting, and feeling"

Artinya, belajar adalah suatu kegiatan yang terjadi secara berulang-ulang, dimana peserta didik menghubungkan pengetahuan yang baru diperolehnya dengan pengetahuan yang telah dipelajarinya, serta mencari cara yang baru dalam berpikir, bertingkah laku dan merasakan.

Seorang guru dapat menggunakan memilih model pembelajaran yang akan digunakannya, sesuai dengan tujuan pendidikan yang hendak dicapainya. Model pembelajaran mempunyai ciri- 
ciri yaitu sesuai teori pendidikan dan teori belajar dari para ahli tertentu, memiliki misi pendidikan tertentu, menjadi pedoman dalam perbaikan proses belajar, mempunyai bagian model yang dinamakan, seperti urutan langkah-langkah pembelajaran, adanya prinsip-prinsip reaksi, sistem sosial dan sistem pendukung, mempunyai efek sebagai akibat dari diterapkannya model pembelajaran, yang meliputi hasil belajar yang bisa diukur, dan Menyusun persiapan untuk mengajar sesui pedoman model pembelajaran (Rusman, 2012: 136)

Discovery berasal dari kata discover yang mempunyai arti menemukan, sedangkan discovery berarti penemuan. Discovery learning mempunyai tiga atribut utama, yaitu menyelidiki dan mencari jalan keluar atas masalah untuk menciptakan, mengintegrasikan dan menyamakan pengetahuan, merangsang siswa untuk belajar sesuai cara mereka sendiri, dimana siswa yang menentukan frekuensi dan urutannya dan adanya aktivitas yang mendorong pengintegrasian dari prinsip pengetahuan yang digunakan yang sudah ada dan menjadi dasar dalam membangun pengetahuan yang baru.

Pendapat lain menyebutkan bahwa model discoveri learning mempunyai kelebihan yaitu Materi pelajaran yang diberikan dengan metode ini daapt bertahan lama, mudah diingat dan daapt diterapkan pada situasi yang baru, Penalaran, analisis dan keterampilan yang dimiliki siswa akan meningkat sehingga mampu memecahkan masalah tanpa pertolongan orang lain, Kreativitas siswa untuk belajar menjadi meningkat dan Siswa menjadi lebih terampil dalam menemukan konsep (Napita, 2013: 15).

Faiz (2010: 37) menyebutkan bahwa model discovery learning mempunyai kelebihan antara lain mampu mengembangkan, memperbanyak kesiapan, serta menguasai keterampilan siswa dalam proses kognitif siswa, pengetahuan yang diperoleh siswa bersifat sangat pribadi sehingga tertanam dalam benak siswa, semangat belajar siswa dapat dibangkitkan, kemampuan siswa dapat dikembangkan, motivasi belajar siswa dapat ditingkatkan dengan mengarahkan cara belajar yang benar, kepercayaan diri siswa meningkat dan siswa menjadi pusat, guru hanya sebagai teman belajar, membantu bila ada permasalahan yang tidak bisa diatasi siswa

Sanjaya (2008: 105) menyebutkan kelebihan menggunakan metode discovery learning adalah mengaktifkan siswa dalam proses belajar mengajar, karena metode ini menuntun siswa untuk berfikir dan menggunakan kemampuannya untuk memecahkan masalah, siswa menjadi paham dengan materi pelajaran, karena mereka mengalami sendiri bagaimana memecahkan masalah tersebut, jawaban yang ditemukan sendiri menimbulkan rasa puas, sehingga dapat meningkatkan minat siswa untuk belajar, siswa mampu mentransfer pengetahuan yang diperolehnya ke dalam berbagai konteks, melatih siswa untuk belajar sendiri, dan menggairahkan situasi belajar di dalam kelas

Selain kelebihan-kelebihan di atas, model pembelajaran discovery learning, juga mempunyai kelemahan yaitu menggunakan waktu yang banyak dan belum tentu siswa tetap bersemangat dalam melakukan penemuanpenemuan, masih sedikit guru yang tertarik menggunakan metode ini, Tidak semua siswa dapat melaksanakan penemuan. Jika arahan guru tidak sesuai dengan kecerdasan siswa dapat merusak pengetahuannya. Selain itu, bimbingan yang terlalu banyak dapat menurunkan inisiatif siswa, dan tidak bisa digunakan dalam setiap topic, Jumlah siswa yang banyak dalam setiap kelas, menyulitkan guru dalam menerapkan metode ini (Suherman, 2004: 214).

Hosnan (2014: 25) menyebutkan beberapa kekurangan model pembelajaran discovery learning adalah (1) waktu yang dibutuhkan model pembelajaran discovery lebih lama; (2) kemampuan berpikir rasional antara satu siswa dengan siswa yang lain tidak sama; (3) Tidak semua materi pelajaran cocok menggunakan metode ini.

Winataputra dkk (2007: 3.19) menyebutkan bahwa tahap-tahap penerapan dalam discovery learning adalah stimulus, mengidentifikasi masalah, mengumpulkan data, mengolah data, verifikasi, dan generalisasi. Sedangkan Carin dan Sund (1985: 181), menemukan terdapat 10 langkah dalam menerapkan discovery learning, yaitu introduction (pendahuluan), review (pengulangan), overview (gambaran), investigation (penyelidikan), representation (representasi), discussion (diskusi), invention (penemuan), application (aplikasi), summary (kesimpulan), assesment (penilaian).

Model discovery learning mempunyai kelebihan yaitu Materi pelajaran yang diberikan dengan metode ini daapt bertahan lama, mudah diingat dan daapt diterapkan pada situasi yang baru, Penalaran, analisis dan keterampilan yang dimiliki siswa akan meningkat sehingga mampu memecahkan masalah tanpa pertolongan orang lain, Kreativitas siswa untuk belajar menjadi meningkat dan Siswa menjadi lebih terampil dalam menemukan konsep. 
Model pembelajaran discovery learning, mendorong guru untuk mampu berperan dalam membuat rencana pembelajaran dimana dalam pelajaran tersebut, permasalahan berpusat pada masalah yang harus diselidiki oleh siswa, memberikan materi pelajaran sebagai dasar bagi siswa dalam memecahkan masalah tersebut, memberikan materi pelajaran dengan cara-cara yang menarik, sebagai tutor atau pembimbing, memberikan penilaian terhadap hasil belajar siswa yang meliputi pemahaman dan penerapan prinsipprinsip belajar dengan tes (Dahar, 2011: 45).

Pembelajaran discovery learning, akan efektif jika dalam proses pembelajaran terjadi proses yang terstruktur dan hati-hati, siswa mempunyai pengetahuan dan keterampilan awal belajar, serta dukungan dari guru kepada siswa untuk melakukan penyelidikan.

Berdasarkan uraian di atas maka tujuan penelitian ini adalah untuk meningkatkan hasil belajar PKn pada materi Integrasi Nasional dalam Bingkai Bhinneka Tunggal Ika di kelas X MIPA SMA Negeri 1 Samigaluh Kulonprogo melalui penerapan model pembelajaran discovery learning dan mengetahui langkah-langkah penerapan model pembelajaran discovery learning dalam meningkatkan hasil belajar PKn pada materi Integrasi Nasional dalam Bingkai Bhinneka Tunggal Ika di kelas X MIPA SMA Negeri 1 Samigaluh Kulonprogo.

\section{METODE PENELITIAN \\ Jenis Penelitan}

Penelitian ini menggunakan penelitian Tindakan Kelas.

\section{Waktu dan Tempat Penelitian}

Penelitian dilaksanakan di SMA Negeri 1 Samigaluh Kulonprogo pada semester II Tahun ajaran 2017/2018.

\section{Subjek Penelitian}

Subjek penelitian yaitu siswa kelas X MIPA SMA Negeri 1 Samigaluh Kulonprogo Tahun Ajaran 2017/2018.

\section{Teknik Pengumpulan Data}

Teknik pengumpulan data mengunakan observasi, dokumentasi, wawancara dan tes.

\section{Prosedur}

Prosedur dan langkah-langkah dalam melaksanakan tindakan mengikuti model yang dikembangkan oleh Kemmis dan Mc taggart berupa siklus spiral refleksi diri yang dimulai dari perencanaan (planning), tindakan (acting), pengamatan (abserving), refleksi (reflecting) dan perencanaan kembali yang merupakan dasar untuk pemecahan masalah.

\section{Teknik Analisis Data}

Teknik analisis data menggunakan metode analisis deskriptif. Penelitian ini dikatakan berhasil apabila dalam proses pembelajaran terdapat peningkatan dengan sekurang-kurangnya persentase $75 \%$ dengan kualifikasi tinggi sedangkan prestasi sesuai dengan kriteria ketuntasan minimal atau KKM yang telah ditetapkan adalah 64 dan tercapai $75 \%$ oleh seluruh siswa.

\section{HASIL DAN PEMBAHASAN \\ Deskripsi Pra Siklus}

Untuk mengetahui kondisi awal hasil belajar siswa diambil dari nilai akhir semester I. Dari nilai tersebut menunjukkan dari 18 orang siswa, yang mendapat nilai di atas KKM berjumlah 4 siswa, sedangkan sebanyak 14 siswa mendapat nilai di bawah KKM. Untuk lebih jelas dapat dilhat pada table 1 berikut ini.

Tabel 1. Hasil Belajar Siswa Pra Siklus

\begin{tabular}{ccccc}
\hline \multicolumn{4}{c}{ Ketuntasan } & $\begin{array}{c}\text { Rata- } \\
\text { Rata }\end{array}$ \\
\cline { 1 - 4 } Tuntas & $\%$ & Belum Tuntas & $\%$ & 63,8 \\
\hline 4 & $22,2 \%$ & 14 & $66,7 \%$ & 63,8 \\
\hline
\end{tabular}

Dari tabel 1 terlihat bahwa siswa yang memperoleh nilai di atas KKM sebanyak 4 anak dari 18 siswa, jika dikatakan dalam persentase, baru mencapai $22,2 \%$ siswa yang mencapai nilai KKM. Hal ini berarti hasil pembelajaran PKn siswa kelas X MIPA belum maksimal.

Untuk kemampuan mengajar, guru mampu mengajar dengan baik, hanya dalam pembelajaran masih menggunakan metode konvensional, yaitu dengan metode ceramah, sehingga siswa merasa bosan dan malas belajar serta siswa sibuk dengan aktivitas sendiri. Berikut ini hasil observasi kemampuan guru sebelum dilakukan tindakan kelas.

Tabel 2. Hasil Observasi Kemampuan Guru Pra Siklus

\begin{tabular}{|c|c|c|c|}
\hline \multirow{2}{*}{$\begin{array}{c}\text { Aspek yang } \\
\text { Dinilai }\end{array}$} & \multicolumn{3}{|c|}{ Nilai } \\
\hline & Rendah & Sedang & Tinggi \\
\hline Kesesuaian RPP & & $\sqrt{ }$ & \\
\hline $\begin{array}{l}\text { Memberikan } \\
\text { motivasi }\end{array}$ & $\sqrt{ }$ & & \\
\hline $\begin{array}{l}\text { Menggunakan } \\
\text { berbagai sumber }\end{array}$ & $\sqrt{ }$ & & \\
\hline $\begin{array}{l}\text { Pembagian waktu } \\
\text { yang tepat }\end{array}$ & & $\sqrt{ }$ & \\
\hline $\begin{array}{l}\text { Menggunakan } \\
\text { multimedia }\end{array}$ & $\sqrt{ }$ & & \\
\hline $\begin{array}{l}\text { Memberikan } \\
\text { umpan balik }\end{array}$ & & $\sqrt{ }$ & \\
\hline $\begin{array}{l}\text { Memberikan } \\
\text { tindak lanjut }\end{array}$ & & $\sqrt{ }$ & \\
\hline
\end{tabular}


Tabel di atas menunjukkan bahwa guru masih belum mampu dalam melakukan pembelajaran, terutama dalam memberikan motivasi kepada siswa untuk belajar. Selain itu, guru juga belum banyak menggunakan berbagai sumber untuk referensi dalam belajar dan mengajar sehingga guru belum menggunakan multimedia dalam proses belajar mengajar.

\section{Siklus I}

\section{Perencanaan Tindakan}

Pada tahap perencanaan tindakan, peneliti dan guru sebagai kolaborator mempersiapkan materi yang akan disampaikan kepada siswa, mempersiapkan RPP, LKS, dan soal evaluasi. Soal diberikan pada setiap akhir siklus dan Menyusun lembar observasi yang digunakan untuk mengetahui aktivitas yang dilakukan oleh siswa selama pembelajaran berlangsung

\section{Tindakan Siklus I}

Tindakan pada siklus I diawali dengan guru dan peneliti menyiapkan materi dan model pembelajaran. Dilanjutkan dengan kegiatan inti, yaitu guru memberikan beberapa pertanyaan kepada siswa, guru memberikan kesempatan kepada siswa untuk melakukan identifikasi terhadap pertanyaan yang diberikan guru, siswa diberikan kesempatan untuk mengumpulkan datadata yang terkait dengan pertanyaan dari buku paket, Siswa melakukan pemeriksaan secara teliti terhadap hasil wawancara dan obsevasi dan menghubungkannya dengan permasalahan yang ada dan menarik kesimpulan. Selanjutnya adalah kegiatan penutup. Dalam kegiatan penutup guru memberikan kesempatan kepada siswa untuk menanyakan hal-hal yang belum jelas tentang materi dan mencatat hal-hal penting tentang materi pelajaran.

\section{Observasi}

Hasil observasi terhadap guru menunjukkan adanya peningkatan dalam cara mengajar yang dilakukan guru. Guru sudah memperbaiki kemampuannya dalam memberikan motivasi dan menggunakan berbagai sumber, sudah menggunakan media lain untuk menunjang proses belajar belajar yaitu menggunakan diskusi. Guru juga sudah memberikan umpan balik kepada siswa sehingga siswa akan memperoleh pemahaman yang lebih mendalam.

Hasil observasi terhadap ssiwa menunjukkan bahwa sebagian besar siswa masih terlihat bermalasmalasan dalam mengerjakan tugas. Hal ini dikarenakan siswa masih bingung dengan model pembelajaran yang diterapkan guru. Beberapa siswa tidak ikut dalam kegiatan pengumpulan data, hanya asyik bercanda dengan teman-temannya.

\section{Refleksi Siklus I}

Secara kuantitas proses pembelajaran dengan menggunakan metode discovery learning mengalami peningkatan. Hal ini dapat dilihat dari hasil evaluasi siklus I. Berikut nilai yang diperoleh siswa.

Tabel 3. Hasil Belajar Siswa Siklus I

\begin{tabular}{ccccc}
\hline \multicolumn{3}{c}{ Ketuntasan } & Rata- \\
\cline { 2 - 3 } Tuntas & $\%$ & Belum Tuntas & $\%$ & Rata \\
\hline 9 & $50 \%$ & 9 & $50 \%$ & 70,6 \\
\hline
\end{tabular}

Berdasarkan tabel 3 dapat dilihat hasil ratarata nilai belajar siswa pada evaluasi siklus I yaitu 70,6, sedangkan persentase ketuntasan siswa pada siklus I sebesar 50\% atau sebanyak 9 siswa dari 18 siswa.

Berdasarkan hasil tes evaluasi setelah tindakan siklus I dapat diketahui adanya peningkatan nilai rerata dari tes evaluasi sebelum tindakan ke tes evaluasi setelah tindakan siklus I, yaitu dari 63,8 menjadi 70,6. Siswa yang sudah tuntas sesuai dengan pencapaian KKM yaitu 9 siswa (50\%). Meskipun demikian, peningkatan tersebut belum maksimal karena dinilai belum mencapai kriteria keberhasilan dalam penelitian yang sudah ditetapkan peneliti yaitu $75 \%$ dari jumlah siswa yang telah mencapai kriteria keberhasilan minimal yaitu $\geq 64$. Sementara hasil tes evaluasi setelah tindakan siklus I baru 50\% siswa yang mencapai nilai $\geq 64$, sehingga dalam penelitian ini tindakan siklus I belum dikatakan berhasil sehingga diadakan siklus II.

Hambatan yang ditemui dalam siklus I antara lain adalah dalam pembagian kelompok dilakukan secara acak. Banyak siswa yang protes dengan kelompok yang telah ditentukan karena tidak satu kelompok dengan teman dekatnya sehingga membutuhkan waktu yang lama dalam membentuk kelompok, Dalam melakukan pembelajaran dengan metode discovery learning guru kurang memberikan penjelasan secara detail mengenai metode ini, sehingga siswa banyak yang kurang paham dan Saat presentasi berlangsung, masih banyak siswa yang tidak mendengarkan dan tidak tertarik memberikan tanggapan.

\section{Siklus II}

\section{Perencanaan Tindakan}

Siklus II dilaksanakan berdasarkan hasil refleksi dari siklus I yang belum mencapai target keberhasilan penelitian. Pada siklus II juga dirancang sebuah desain pembelajaran menggunakan metode discovery learning dengan menggunakan media power point sebagai alat untuk mempresentasikan hasil diskusi kelompok. Sama dengan siklus I, pada siklus II juga 
menyiapkan rencana pelaksanaan pembelajaran, instrumen soal utuk mengukur kemampuan kognitif siswa dan juga lembar observasi untuk mengamati keaktifan siswa selama proses pembelajaran.

\section{Tindakan Siklus II}

Tindakan siklus II diawali dengan menyiapkan materi. Guru mengecek kondisi kelas dan kesiapan siswa. Selanjutnya guru membuka pelajaran dengan salam dan berdoa serta mengabsen siswa. Guru juga menjelaskan tujuan pembelajaran yang ingin di capai dan memotivasi siswa bahwa dengan pembelajaran PKn hari ini dapat menumbuhkan semangat kebhinekaan siswa. Dilanjutkan dengan kegiatan inti dengan memberikan tindakan memberikan satu pertanyaan kepada siswa untuk didiskusikan dengan kelompoknya, memberikan kesempatan kepada siswa untuk melakukan identifikasi terhadap pertanyaan yang diberikan guru, siswa diberikan kesempatan untuk mengumpulkan data-data yang terkait dengan pertanyaan, siswa mengolah data yang diperoleh melalui kegiatan wawancara dan observasi dengan beberapa narasumber, siswa melakukan pemeriksaan secara teliti terhadap hasil wawancara dan obsevasi dan menghubungkannya dengan permasalahan yang ada, Siswa mempresentasikan hasil temuannya di depan kelas dengan media power point dan menarik kesimpulan. Selanjutnya kegiatan penutup dengan memberikan kesempatan kepada siswa yang belum mengerti tentang materi yang diajarkan. Guru menutup pelajaran dengan ucapkan salam.

3. Observasi Siklus II

Hasil observasi terhadap guru menunjukkan bahwa kemampuan guru dalam mengajar sudah sangat baik. ditunjukkan dengan hasil nilai observasi yang semuanya memperoleh nilai tinggi, baik dalam pelaksanaan RPP, memberikan motivasi, menggunakan berbagai sumber, pembagian waktu yang tepat, menggunakan multimedia, memberikan umpan balik dan memberikan tindak lanjut.

Hasil observasi terhadap siswa menunjukkan bahwa sebagian besar siswa sudah terlihat aktif dalam berdiskusi dengan teman kelompoknya. Sebagian besar juga sudah ikut dalam kegiatan pengumpulan data, baik yang mencari dari buku paket ataupun dengan melakukan wawancara dengan narasumber.

\section{Refleksi Siklus II}

Hasil belajar siswa kelas X MIPA SMA N 1 Samigaluh pada siklus II juga mengalami peningkatan, terlihat dari hasil evaluasi siklus II. Berikut nilai yang diperoleh siswa.
Tabel 4. Hasil Belajar Siswa Siklus II

\begin{tabular}{ccccc}
\hline & \multicolumn{2}{c}{ Ketuntasan } & $\begin{array}{c}\text { Rata- } \\
\text { Rata }\end{array}$ \\
\hline Tuntas & $\%$ & Belum Tuntas & $\%$ & \\
\hline 18 & $100 \%$ & & $0 \%$ & 85,6 \\
\hline
\end{tabular}

Berdasarkan tabel 4 dapat dilihat hasil ratarata nilai belajar siswa pada evluasi siklus II yaitu 85,6 , sedangkan rata-rata nilai belajar siswa pada siklus I sebesar 70,6.

Berdasarkan hasil tes evaluasi setelah tindakan siklus II dapat diketahui adanya peningkatan nilai rerata dari tes evaluasi sebelum tindakan ke tes evaluasi setelah tindakan siklus I, yaitu dari 63,8 menjadi 70,6 dan pada siklus II menjadi 85,6. Siswa yang sudah tuntas sesuai dengan pencapaian KKM yaitu 18 siswa (100\%). Peningkatan tersebut maksimal karena dinilai sudah memenuhi kriteria keberhasilan dalam penelitian yang sudah ditetapkan peneliti yaitu 75\% dari jumlah siswa, telah mencapai criteria keberhasilan minimal. Oleh karena itu, tidak perlu dilakukan siklus III.

\section{PEMBAHASAN}

Hasil deskripsi pra siklus menunjukkan bahwa nilai rata-rata hasil belajar siswa sebesar 63,8 dengan jumlah siswa yang tuntas sebesar $22,2 \%$. Hasil observasi terhadap aktivitas guru menunjukkan bahwa guru masih belum mampu dalam melakukan pembelajaran, terutama dalam memberikan motivasi kepada siswa untuk belajar. Selain itu, guru juga belum banyak menggunakan berbagai sumber untuk referensi dalam belajar dan mengajar serta guru belum menggunakan multimedia dalam proses belajar mengajar, sehingga hasil belajar siswa belum sesuai dengan yang diharapkan. Berdasarkan hasil observasi tersebut, maka guru menggunakan model pembelajaran discovery learning untuk meningkatkan hasil belajar siswa.

Hasil siklus I menunjukkan bahwa setelah menggunakan model pembelajaran discovery learning, nilai rata-rata siswa meningkat menjadi 70,6. Selain itu, jumlah siswa yang tuntas meningkat menjadi 50\%. Hasil siklus II menunjukkan bahwa nilai rata-rata hasil belajar siswa meningkat menjadi 85,6 dengan ketuntasan sebesar $100 \%$, dimana sebelumnya pada siklus I rata-rata hasil belajar siswa hanya 70,6 dengan ketuntasan sebesar 50\%. Peningkatan hasil belajar siswa pada siklus II ini menunjukkan bahwa model pembelajaran discovery learning efektif meningkatkan hasil belajar siswa pada materi Integrasi Nasional dalam Bingkai Bhinneka Tunggal Ika. 
Untuk lebih jelasnya dapat dilihat pada gambar di bawah ini.

\section{Hasil Belajar}

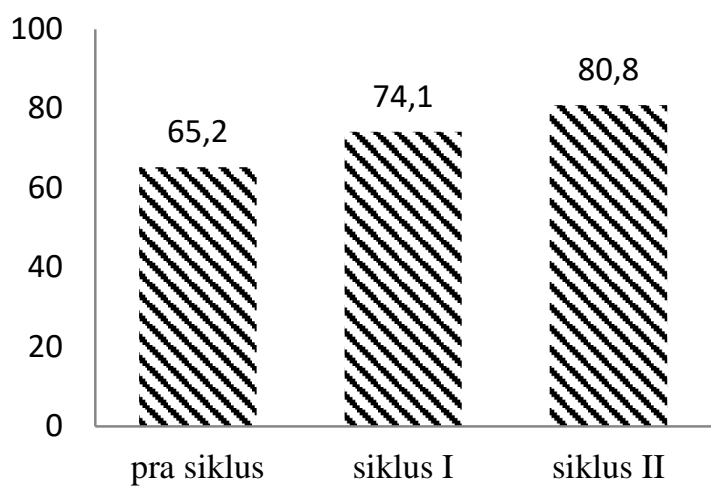

Gambar 1. Peningkatan Nilai Rata-Rata Hasil Belajar Siswa pada Pra Siklus, Siklus I, dan Siklus II

Berdasarkan gambar 1, nilai rata-rata hasil belajar siswa menunjukkan peningkatan pada tiap siklusnya. Dimana nilai rata-rata hasil belajar siswa pada pra siklus adalah 65,2, yang kemudian pada siklus I meningkat menjadi 74,1. Pada siklus II terjadi peningkatan menjadi 80,8 . Hal ini disebabkan karena metode discovery learning menuntut siswa untuk lebih aktif dalam pembelajaran, dimana siswa dituntut untuk menemukan sendiri pemecahan atas masalah yang terjadi, dan menyimpulkan dengan bahasa sendiri. Hal ini menyebabkan siswa menjadi mudah untuk memahami materi pelajaran.

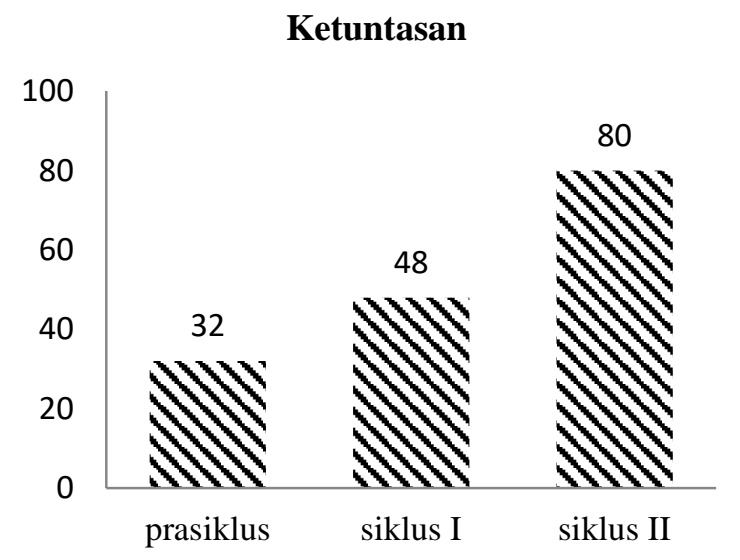

Gambar 2. Peningkatan Persentase Ketuntasan Siswa pada Pra Siklus, Siklus I, dan Siklus II

Berdasarkan gambar 2, ketuntasan keseluruhan siswa pada pra siklus 32\% dengan jumlah siswa yang tuntas hanya 8 siswa. Pada siklus I terjadi peningkatan yang cukup baik, persentase ketuntasan keseluruhan siswa naik menjadi $48 \%$ dengan jumlah siswa yang tuntas sebanyak 12 siswa. Pada siklus I persentase ketuntasan keseluruhan siswa belum mencapai indikator keberhasilan, dimana indikator keberhasilannya adalah persentase ketuntasan keseluruha siswa sebesar $75 \%$ maka perlu dilanjutkan dengan siklus II. Pada siklus II peningkatan persentase ketuntasan keseluruhan sangat baik yaitu meningkat menjadi $80 \%$ dengan jumlah siswa yang tuntas sebanyak 20 siswa. Meningkatnya ketuntasan siswa dalam belajar dikarenakan siswa sudah mampu memahami materi pembelajaran PKn dengan baik setelah dilakukan pembelajaran dengan metode discovery learning. Pelaksanaan pembelajaran yang mengajak siswa untuk lebih aktif dalam belajar membuat siswa tidak merasa bosan sehingga mampu meraih nilai di atas KKM yang ditetapkan.

Peningkatan hasil belajar ini mengindikasikan bahwa model pembelajaran discovery learning tepat digunakan dalam mata pelajaran PKn materi Integrasi Nasional dalam Bingkai Bhinneka Tunggal Ika. Hal ini disebabkan dengan menggunakan model pembelajaran discovery learning, siswa dituntut untuk mencari jalan keluar sendiri atas masalahmasalah yang terkait kebhinnekaan, sehingga hasilnya terekam lebih lama dalam benak siswa, yang pada akhirnya siswa menjadi paham dan hasil belajar siswa juga akan meningkat.

Selain itu, penggunaan model pembelajaran ini menghilangkan kebosanan siswa dalam belajar $\mathrm{PKn}$, sehingga siswa lebih bersemangat dalam menyerap materi pelajaran.

\section{SIMPULAN}

Penelitian ini menyimpulkan bahwa Model pembelajaran discovery learning dapat meningkatkan hasil belajar PKn materi Integrasi Nasional dalam Bingkai Bhinneka Tunggal Ika pada siswa kelas X MIPA SMA N 1 Samigaluh. Ditunjukkan dengan adanya peningkatan rata-rata hasil belajar siswa pada pra siklus sebesar 71,6, dengan ketuntasan $22,2 \%$, siklus I meningkat menjadi 76,3 dengan ketuntasan 50\% dan siklus II meningkat menjadi 85,6 dengan ketuntasan 100\%. Penelitian ini juga menunjukkan bahwa langkahlangkah penerapan model pembelajaran discovery learning dalam meningkatkan hasil belajar PKn materi Integrasi Nasional dalam Bingkai Bhinneka Tunggal Ika di SMA N 1 Samigaluh Kulonprogo adalah melalui pemberian stimulus, mengidentifikasi masalah, mengumpulkan data, pengolahan data, memverifikasi dan terakhir adalah dengan generalisasi. 


\section{DAFTAR PUSTAKA}

Abruscato, J and DeRosa, D.A., 2010. Teaching Children Science A Discovery Approach, United States of America: Allyn and Bacon

Ali, Muhammad. 2000. Penelitian Pendidikan Prosedur dan Strategi. Bandung: Angkasa

Arikunto, Suharsimi. 2006. Prosedur Penelitian Suatu Pendekatan Praktik. Jakarta: PT. Rineka Cipta

Dahar, Ratna Willis. 2011. Teori Belajar dan Pembelajaran. Jakarta: Erlangga

Dimyati dan Mudjiono. 2006. Belajar dan Pembelajaran. Jakarta: PT Rineka Cipta

Faiz. 2010. Pengaruh Penggunaan Metode Discovery Inquiry terhadap Kemampuan Kognitif Fisika Siswa Di SMA Ditinjau dari Kreativitas Belajar Fisika Siswa. Skripsi. Universitas Sebelas Maret Surakarta
Hosnan, M. 2014. Pendekatan Saintifik dan Kontekstual dalam Pembelajaran Abad 21. Bogor: Ghalia Indonesia

Rusman. 2012. Model-Model Pembelajaran. Jakarta: Rajagrafindo Persada

Sanjaya, Wina. 2008. Strategi Pembelajaran Berorientasi Standar Proses Pendidikan. Jakarta: Kencana Prenada Media grouf

Sugihartono, dkk. 2007. Psikologi Pendidikan. Yogyakarta: UNY Press

Suryobroto. 2002. Proses Belajar Mengajar di Sekolah. Jakarta: Rineka Cipta

Trianto. 2007. Model-model Pembelajaran Inovatif Berorientasi Konstruktivistik, Jakarta: Prestasi Pustaka Publisher

Winataputra, Udin S dkk. 2007. Teori Belajar dan Pembelajaran. Jakarta: Universitas Terbuka 